\title{
EDIBLE COATING QUALITY WITH THREE TYPES OF STARCH AND SORBITOL PLASTICIZER
}

\author{
Retno Utami Hatmi ${ }^{1, *}$, Erni Apriyati ${ }^{1}$, and Nurdeana Cahyaningrum ${ }^{l}$ \\ ${ }^{1}$ Assessment Institute for Agricultural Technology Yogyakarta, Indonesian Agency for Agricultural Research and \\ Development, Ministry of Agriculture, Stadion Maguwoharjo Street No. 22 Ngemplak Sleman Yogyakarta
}

\begin{abstract}
Edible coating is one form of packaging technology with environmentally friendly theme. The raw materials of edible coating derived from nature, while the waste is decomposed or even zero waste. The research of edible coating using experimental design RAL (completely randomized design) with two factors, namely the type of raw material used tuber starch (cassava, arrowroot and canna) and the percentage of starch $(3 \%, 4 \%$ and $5 \%)(b / v)$ with three replications time. The quality analisys of edible coating includes the physical properties (thickness $(\mathrm{mm})$, tensile strength $(\mathrm{N})$ and elongation $(\mathrm{mm})$ ) and chemical properties (moisture content (\%), solubility (\%), the water vapor transmissin rate ( $\mathrm{g} /$ hour) and peroxide $(\mathrm{mek} / \mathrm{kg})$. The research showed that the edible coating with sorbitol plasticizer of arrowroot starch $4 \%$ provide best physicochemical properties (thickness $0,09 \mathrm{~mm} ; 1,63 \mathrm{~N}$ tensile strength; elongation $84,38 \mathrm{~mm}$; water content of $11.19 \%$; solubility of $31.40 \%$; the transfer of water vapor $0,16 \mathrm{~g} / \mathrm{h}$ and $3,20 \mathrm{mek} / \mathrm{kg})$.
\end{abstract}

\section{INTRODUCTION}

The proper packaging techniques can improve the quality and reduce damage to foodstuffs. One of the primary packaging technologies in food is edible coating. Edible coating is a thin layer on the surface of foodstuffs made from edible material. Coating aims to provide selective detentions for mass transfer (oxygen, moisture, light, lipids, and solutes) and as a carrier of an additive and to improve the handling of food $[1,2]$. Food coating can reduce weight loss and total acid, able to maintain fruit color, maintain sensory quality, prevent rancidity, extend shelf life, protect from the microbial growth [3, 4, 5]. [6] also state that the coating was effective in delaying ethylene biosynthesis and reducing respiration rate.

Edible coating materials directly affect the morphology and characteristics of produced by coating [1]. The edible packaging materials can be made from polysaccharides, proteins and fats, as a single component or as a mixture [7]. Polysaccharide based coatings (cellulose and its derivatives, chitin and chitosan, starch, pectin, pullulan, and alginate), lipid based (waxes and paraffin, acetoglycerides, resins), and based on proteins (corn, gelatin, wheat gluten) [5].

The polysaccharide is widely used as an edible coating is starch $[8,9]$. Starch polysaccharide content is glucomannan. This is to function as film-forming. The advantages of starch as the main material of edible

Corresponding author: tamibptp@yahoo.co.id coating are as an good oxygen barrier, because starch has a structure that is compact and has a low solubility $[10,11]$. The others advantages are ready availability, low cost, good filmogenic capacity, forming colorless and tasteless films [12]. Starch component which is used in the manufacture of edible coating is amylose. Amylose produce films that are stronger than the amylopectin [13]. Each type of starch has amylose content is different. Amylose content in the starch is divided into four groups, ie very low $(<9 \%)$, low (9$20 \%$ ), medium (20-25\%), and high (25-30\%) [14]. Cassava, arrowroot and canna in a row has amylose content of $19.8 \% \pm 0.38$ (low); $20.8 \pm 0.42$ (lowmedium) and $31.7 \pm 0.33$ (high) [15]. This is different from the opinion of [16] which states that arrowroot is a source of starch with high amylose content $(35 \%)$. The size and shape of starch granule will affect the quality of the product processed Starch. Granule size also affects properties of starch such as starch composition, gelatinization temperature, crystallization and solubility [15].

Plasticizers in the edible coating categorized into three, ie: 1. mono-, di-, and oligosaccharides, 2. polyols (glycerol, polyethilen glycol and sorbitol) and 3. lipids and their derivatives [17]. Polyols have the ability to absorb the water in food products, molecular weight and low toxicity. Sorbitol is reduced glucose formed by the oxidation of glucose. Sorbitol has a crystal form, soluble and stable in water although the long heating [18]. Sorbitol significantly increases the percentage of the 
extension of edible coatings exponentially with an increase in humidity, and decreases the rate of water vapor transmission [19]. The additional plasticizer in the edible coating suspension aims to restrain the coating cracks in the coated product. The addition levels of plasticizer must be in accordance with the rules of the range of $0.1 \%-10 \%$ of the total weight [20].

The purpose of this research is to study some types of starch (cassava, arrowroot and canna) in three levels of concentrations $(3 \%, 4 \%$ and $5 \%)$ to the quality of edible coating which is applied on the apples. This study is expected to provide scientific information on the physicochemical properties of produced by edible coating.

\section{MATERIAL AND METHODE}

Research conducted at the Laboratory of Postharvest and Agricultural Machinery BPTP Yogyakarta. The materials that is used for edible coating apples processing are starch and plasticizer (sorbitol). Starch was made of three types of local tuber from Kulon Progo Regency Yogyakarta. Research are arranged in a completely randomized design with two factors and three replications. The first factor is the type of starch (cassava, arrowroot and canna) and the second factor is the levels of starch $(3 \%, 4 \%$ and $5 \%)(w / v)$ [21]. The research stage consisted of starch processing and the edible coating suspension processing (Figure 1 and 2). Physicochemical qualities edible coating was analyzed according to several parameters including the thickness (Digimatic Micrometer), tensile strength and percent elongation (Mechanical Universal Testing Machine), moisture content (Oven Method), solubility [22], the water vapor transmission rate (Water Vapor Transmission Rate tester Bergerlahr with cup Methode) and peroxide (Iodometry Titration). Data were analyzed using Analysis of Variant (ANOVA) followed by real different test (BNT) with significance level of $5 \%(\alpha=$ $0.05 \%$ ).

\section{RESULT AND DISCUSSIONS}

The source of starch, concentration and type of plasticizer affect the properties of the coating/film such as the thickness of the layer, tensile strength, the permeability of water vapor, and the solubility of the film [23].

The use of plasticizers, surfactants, lipids or other polymers in edible coatings are intended to improve the functional properties of starch-based films/coatings [12]. Sorbitol platisizers in composite films actually produce lower water vapor permeability and higher tensile strength [24]. Research by [25] states that sorbitol produced films more resistant to puncture than glycerol.
Edible coating quality measurement in this research was based on physicochemical properties testing. Testing of physicochemical properties of edible coating is done by making a sheet from edible suspension. The following results of testing the quality of edible coating on the three

types of tubers (cassava, arrowroot and canna) in the three concentrations levels $(3 \%, 4 \%$ and $5 \%)$.

\section{Fresh tubers}

Unpeeled, washed and be shredded

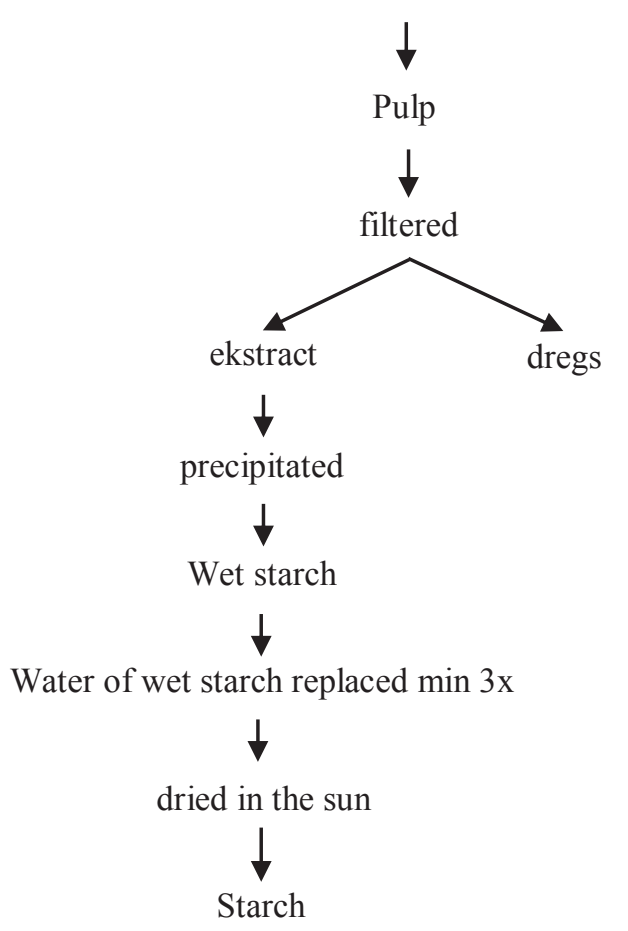

Fig 1. The starch manufacturer process

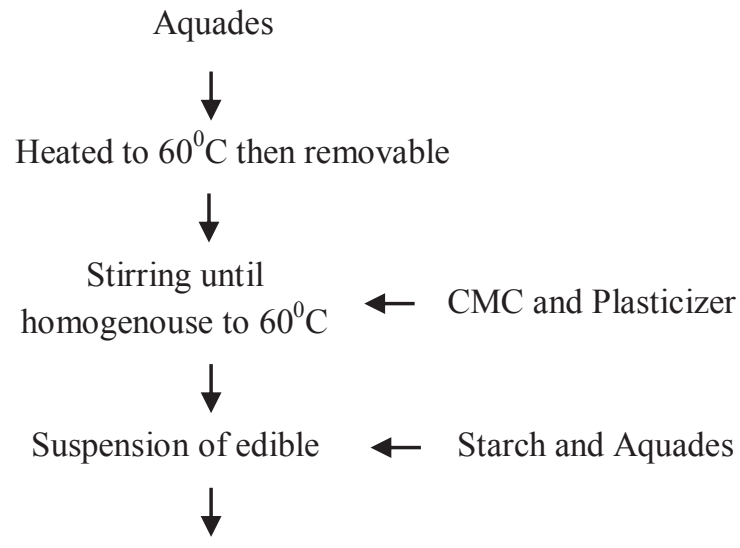

Heated for 20 minutes

Suspension ready to used

for Edible Coating 
Figure 2. The edible coating manufacturer process 


\subsection{The Physical Properties of Edible Coating}

\subsubsection{Thickness}

One of the characteristics of edible coating that greatly affects the biological nature and shelf life of coated food products is thickness. The ideal thickness for edible coatings or films is $\leq 0.25 \mathrm{~mm}$ [26].

The results of variance analysis showed that the interaction of treatment types and concentrations starch provide result were not significantly different to the thickness of edible coating. The edible coating thickness ranged from 0.06 to $0.125 \mathrm{~mm}$ (Fig 3.). These results are in accordance with the characteristics of the thickness of the edible coating $(\leq 0.25 \mathrm{~mm})$.

There are two treatments that show different results, ie in the concentration of arrowroot tubers $3 \%$ and $5 \%$. In both treatments, the edible coating thickness is much higher $(0.7$ and $0.65 \mathrm{~mm})$. This is not in line with the opinion of [16] which states that the film thickness of arrowroot starch ranges from $0.026 \pm 0.008$ to $0.082 \pm$ $0.011 \mathrm{~mm}$. This difference may be due to the current instability create a thin layer from the edible coating suspension. The thickness of edible coating from cassava starch and type of plasticizer "sorbitol" ranges from 0.06 to $0.100 \mathrm{~mm}$. Its thickness is similar to the research of [25] around $0.059 \pm 0.005$ to $0.081 \pm 0.005$.

Factors that influence the differences in edible coating thickness is the solution physical properties (density, viscosity, surface tension, drying time) and the coating formation technique [27].

Thick coating can restrict the exchange of respiratory gases, thus causing a product accumulated ethanol is quite high and increases off flavors [28]. Edible coating thickness increase proportional to the increase in the concentration starch used. This is because at the same volume, the number of constituent polymers and total dissolved solids that make up the layer increases.

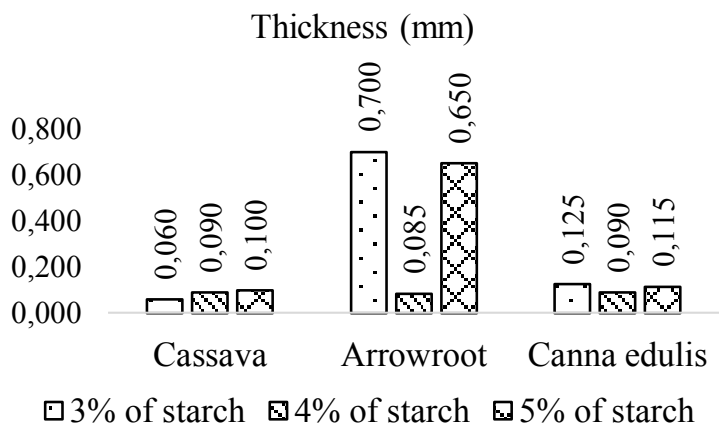

Figure 3. The Thickness of Edible Coating
Some studies state that the tensile strength of coatings or films using material from polysaccharides (waxy maize, tapioca, potato, wheat, corn) vary between 10-100 MPa [26].

The observation of [29] states that the tensile strength of edible coating increases with increasing starch concentration. The addition of starch concentration causes higher amylose content, so the more matrices are formed, the stronger and the greater the tensile strength produced.

The influence of types and concentrations starch to the tensile strength is presented in Figure 4. The results of variance analysis showed that the interaction of types and concentrations starch significantly. Cassava starch provide the lowest the tensile strength values for all concentrations ( 0.54 to $1.10 \mathrm{~N} / \mathrm{mm} 2)$ compared with arrowroot (1.63 to $1.83 \mathrm{~N} / \mathrm{mm} 2$ ) and canna (2.44 to 4.06 $\mathrm{N} / \mathrm{mm} 2$ ). While the canna starch has the highest tensile strength values (with a rigid gel strength) forming edible coating which is more rigid than edible coating from cassava and arrowroot starch. Increasing concentrations of starch and amylose in the film suspension increases the number of hydroxyl groups and produce rigid film [30]. The higher levels of amylose and starch concentrations used, the edible coating come stronger. Cassava is a tuber that has a low amylose content while arrowroot and canna into the medium and high category.

Each type of starch has different levels of amylose and amylopectin (cassava, arrowroot, and canna). Amylose and amylopectin exhibit different behaviors with respect to gelation and the development of crystallinity [19].

Amylose crystallinity is only slightly affected by the addition of plasticizers, whereas amylopectin does not have enough time to crystallize before the water content reaches very low values during the drying process Rindlav-Westling et al., 1998 in [19].

Plasticizers increase the crystallinity in amylopectin. Increased crystallinity makes cassava flour films more fragile, increases tensile strength and modulus of elasticity and strain is relatively lower [19].

This is consistent with the opinion of [19], that the concentration and type of starch (differences in the composition of amylose and amylopectin in each type of starch) greatly determine the increase in tensile strength.

\subsubsection{Tensile Strength}




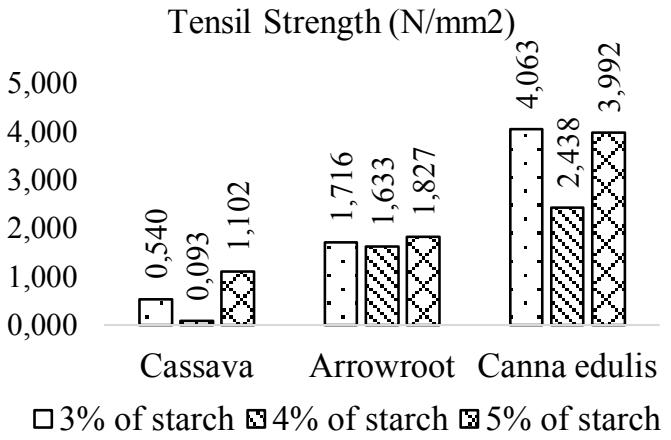

Figure 4. Tensil Strength of Edible Coating

\subsubsection{Elongation}

Starch-based coating is easily broken, the higher the concentration would reduce flexibility [30]. Elongation inversely proportional to the tensile strength. [26] mentioned that the elongation is expressed as the percentage of change in the original length of film before breaking and gives a measure of the extensibility of the films, and edible films or coatings made from polysaccharides have elongation values ranging from 1$80 \%$. A high elongation value indicates the edible coating is getting more elastic.

Research by [29] states that starch content has no significant effect on the elongation of edible coatings, because it is influenced by the main constituent components (starch) and additives (plasticizers) (both types and levels).

Results of variance analysis showed that the canna starch provides low elongation properties for all levels of concentration $(42,94 \%-61,19 \%)$ than arrowroot starch $(67,86 \%$ - 141,36\%) and cassava starch $(107,47 \%$ 130,91\%) (Fig 5.). In starch-based edible coating canna, the increase in concentrations starch causes elongation value go down. The results of the study are consistent with observations by [31] which states that the addition of starch will increase the ratio of starch and plasticizer, so that the characteristics of plastic edible coating (elongation) decreases. Conversely, the arrowroot and cassava starch, the starch concentration rises, the elongation becomes greater. This is in line with the report of [32] which states that the elongation of edible coating tends to increase with the addition of cassava starch to the fixed amount of plasticizer (glycerol).

The difference the size and shape of three types of starch granules affect the value of the elongation. Canna starch has a starch granule size of the biggest, namely $42,3 \mu \mathrm{m}$ while cassava and arrowroot is $15.9 \mu \mathrm{m}$ and 21.1 $\mu \mathrm{m}$ [15]. The larger the size of the granules causes the chain bond more easily broken, so the edible coating made from starch canna have properties more rigid, brittle and inelastic.

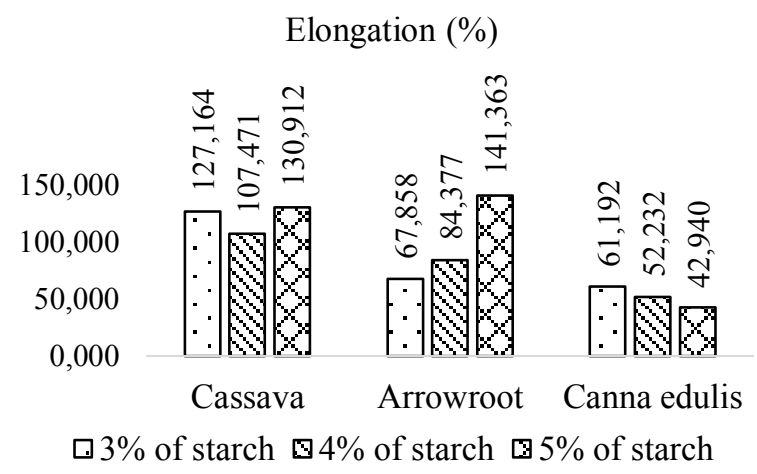

Figure 5. Elongation of Edible Coating

\subsection{Chemical Properties of Edible Coating}

\subsubsection{Moisture Content}

Water content in food affect the stability, appearance, texture and taste of food, as well as an controlling the growth of microorganisms [33]. Edible coating that have low water levels will be better able to reduce the damage and extend the shelf life of foodstuffs.

The water content of edible coating ranged between $11.34 \%-45.27 \%$ in the combined treatment of various types and concentrations starch (Fig 6.). Edible coatings are made from cassava and arrowroot starch has a low water content, ie $11.345 \%-16.94 \%$, while those made from canna starch has high water content $(26.40 \%$ $45.27 \%)$.

Observation of [34] states that the type of plasticizer and the concentration of plasticizer have a significant effect on the edible coating moisture content produced. This is in line with research by [19] which states that the concentration and hydrophilicity of sorbitol is a factor in determining the moisture affinity of edible coatings based on cassava flour.

The use of sorbitol plasticizers produces lower water content compared to glycerol [34]. This is reinforced by the opinion of [10] who said that sorbitol has a lower ability to bind water compared to glycerol.

The difference in molecular weight of each type of plasticizer and starch can cause an increase in water content. The greater molecular weight causes a greater gap between molecules, so that it can be inserted by water molecules and ultimately results in an increase in water content Goldberg and Williams, 1988 in [34].

Starch is a polysaccharide containing amylose and amylopectin. Amylose and amylopectin content of each type of starch is different. Canna starch has the highest amylose content, followed by arrowroot starch and cassava starch. Amylose is a type of starch that is soluble in water and has a molecular weight of 50,000-200,000, while amylopectin is a type of starch that is insoluble in 
water with a molecular weight of 70,000 to one million. It is estimated that the water content of edible coatings based on canna starch is higher than the other two types of starch.

Moisture Content (\%)

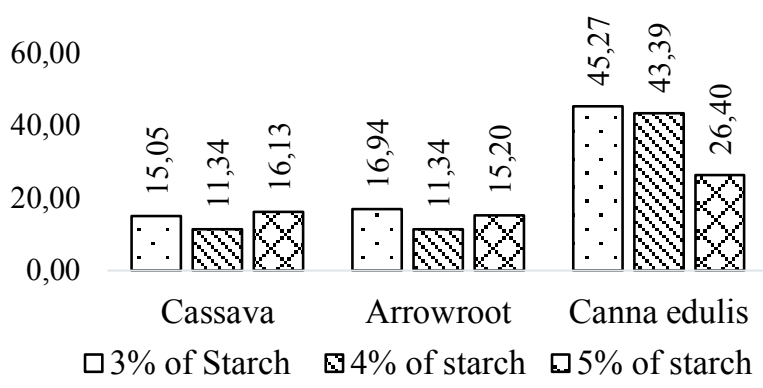

Figure 6. Moisture Content of Edible Coanting

\subsubsection{Solubility}

The value of solubility in edible coatings is used to determine the ability to dissolve and hold water. High solubility will produce edible coatings that dissolve easily but do not have the ability to retain water.

Increased starch concentration (polysaccharide type) tends to reduce the value of the solubility of edible film. This is due to the level of dissolved solids and the number of bonds between molecules in the edible coating solution which increases $[35,29]$. On the other hands, [36] explained that the addition of sorbitol can reduce intermolecular forces so as to increase water solubility.

Results of variance analysis to solubility of edible coating made from cassava starch, arrowroot and canna in three levels of concentrations showed significant differences (Fig 7.). Solubility ranges between $26.421 \%$ - 39.513\%. Edible coatings are made from starch canna has the highest solubility $(39.513 \%)$ and indicate if the starch concentration increases, the solubility decreases. The size and shape of starch granule also affects the solubility of edible coating [15].

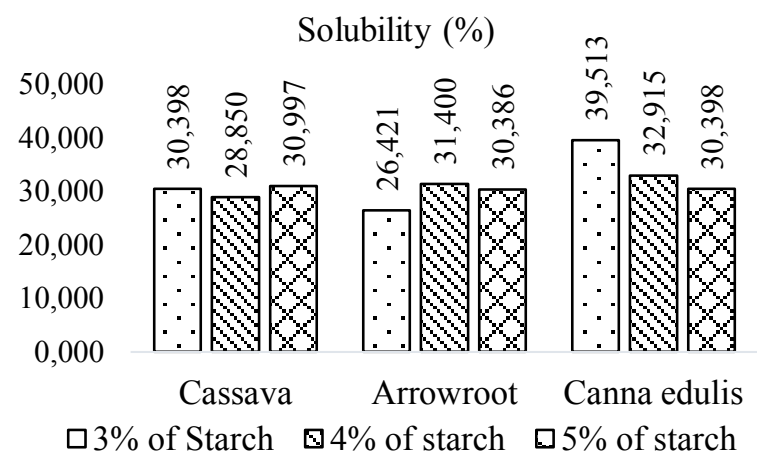

Figure 7. The solubility of Edible Coating

\subsubsection{Water Vapour Transmission Rate (WVTR)}

[37] mentioned that the edible coatings made from starch have good ability as a gas barrier $(\mathrm{O} 2$ and $\mathrm{CO} 2)$ but are not good as a water barrier. This is due to its high hydrophilicity and the presence of polar plasticizing molecules (to improve the flexibility of edible coatings). The addition of sorbitol on starch-based edible coating solution is able to improve the flexibility of the film, mechanical properties, the permeability of oxygen and water vapor [37]. Sorbitol is a type of plasticizer suitable for edible coatings made from starch.

The results of variance analysis, all treatment types and the concentration of starch to the water vapor transmission (WVTR) show significant differences. In the third types starch with 3\% concentration level has WVTR fairly stable between 0.161 to 0.172 $\mathrm{gH} 2 \mathrm{O} / \mathrm{m} 2$ hour. This is consistent with what was stated by [16] that starches and plasticizers (glycerol) in edible coatings have no significant effect on water vapor permeability, while in the level of concentration of $4 \%$ and $5 \%$ indicate that the increasing concentration of starch cause WVTR go down (Fig 8.). WVTR declined due to the increase in soluble solids in suspension, as well as the increase in the concentration of amylose molecules forming hydrogen bonds stronger, resulting in a compact structure [7]. Cassava starch and canna in the $4 \%$ concentration gives the highest WVTR values $(0.214$ and $0.225 \mathrm{gH} 2 \mathrm{O} / \mathrm{m} 2$ hour). From the three types of starch, arrowroot of starch types which have the lowest WVTR in the all concentration levels.

\section{Water Vapor Trnasmission Rate} (gH2O/m²hour)

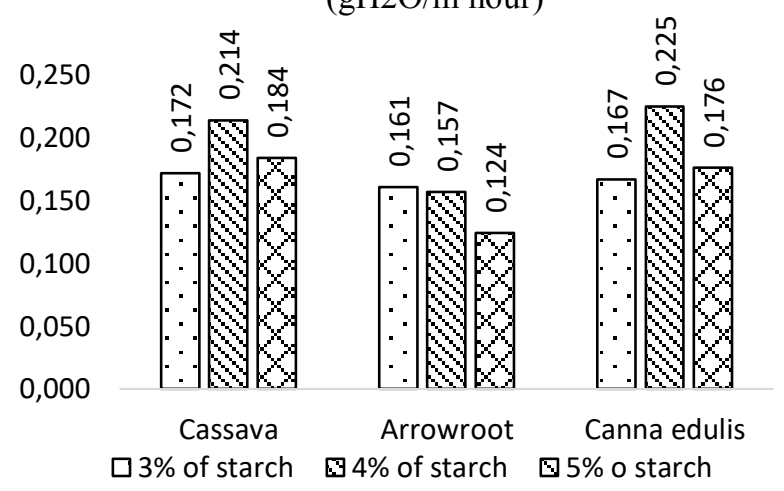

Figure 8. Water Vapor Transmission rate of Edible Coating

\subsubsection{Peroxide}

Peroxide was the amount of fat index that has undergone oxidation. Peroxide is very important to identify the level of fat oxidation. Fat in the manufacture of edible coating role as a carrier of flavor, dyestuff and forming texture. Sorbitol is a type of synthetic lipid that function as plasticiser. Results of variance analysis showed that the peroxide from all treatments was significantly 
different. Peroxide of the range of $3.203-4,050 \mathrm{mek} / \mathrm{kg}$ (Fig. 7). Peroxide is included in the low threshold. The high value of peroxide can accelerate the process of rancidity and undesirable flavor in the food.

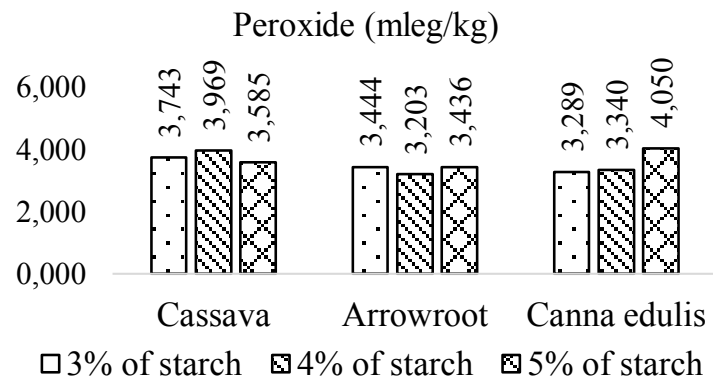

Figure 9. Peroxide of Edible Coating

\section{CONCLUSION}

Each type of starch has amylose content, size and shape of the granules. Differences in the type and level of starch concentration was significantly determines the quality of the edible coating. Edible coatings having good physical properties: the thickness of thin $(<0.20$ $\mathrm{mm}$ ), low tensile strength (not brittle / rigid) and high elongation (elastic). Edible coatings are both also have the following chemical properties of the water content, water vapor transmission and low peroxide and has a great solubility. Seventh physicochemical properties of the best edible coating produced by the type of arrowroot starch at a concentration level of $4 \%$.

\section{REFERENCES}

(1) J.M. Krochta, E.A. Baldwin, and M.O.N. Carriedo. Edible coating and film to Improve Food Quality. (Tehcomic Publish. Co. Inc. USA, 1994)

(2) J.M. Krochta, and C.D.M. Johnston. Edible and biodegradable polymer film: Challenges and opportunities. FT. 51(2):61-74 (1997)

(3) Handayani, M. N., Karlina, S., Sugiarti, Y., \& Cakrawati, D. (2018). Application of edible coating from cassava peel - Bay leaf on avocado. Journal of Physics: Conference Series, 1013(1). https://oi.org/10.1088/1742-6596/1013/1/012168

(4) Ulusoy, B. H., Yildirim, F. K., \& Hecer, C. (2018). Edible Films and Coatings: A Good Idea From Past to Future Technology. Journal of Food Technology Research, 5(1), 28-33. https://doi.org/10.18488/journal.58.2018.51.28.33

(5) Hassan, B., Chatha, S. A. S., Hussain, A. I., Zia, K. M., \& Akhtar, N. (2018). Recent advances on polysaccharides, lipids and protein based edible films and coatings: A review. International Journal of Biological Macromolecules, 109(June 2018), 1095-1107. https://doi.org/10.1016/j.ijbiomac.2017.11.097

(6) Thakur, R., Pristijono, P., Bowyer, M., Singh, S. P., Scarlett, C. J., Stathopoulos, C. E., \& Vuong, Q. V. (2019). A starch edible surface coating delays banana fruit ripening. $L w t, 100,341-347$. https://doi.org/10.1016/j.lwt.2018.10.055

(7) J. F. Polnaya, Haryadi, dan Marseno, D.W. Karasteristik Edible Film Pati Sagu Alami dan Termodifikasi. Majalah Ilmu dan Teknologi Pangan. Vol. XXVI (3):179-241 (2006)

(8) L. Jokay, G.E. Nelson, and E.C. Powell. Amylaceous coatings for foods. FT. 21:10641066 (1967)

(9) J.L. Willet, B.K. Jasberg, and C.L. Swanson. Melt rheology of thermoplastics starch. Dalam: Polymers from agricultural coproduct. Pp.:50-68. (American Chemical Society, Washington, D.C., 1994)

(10) T.B. McHugh, R. Avena-Bustillos, and J.M. Krochta. Permeability properties of edible film in J.M. Krochta, E.A. Baldwin, and M.O. NisperosCarriedo, (eds.) Edible Coatings and Films to Improve Food Quality. (Technomic Publication Company, Inc. Lancaster, U.S.A. 1994)

(11) $\mathrm{Wu}$ and Zhang. Structure and properties of casting films blended with starch and waterborne polyurethane. JAPS. Vol. 79 (11):2006-2013 (2001).

(12) Sapper, M., \& Chiralt, A. (2018). Starch-based coatings for preservation of fruits and vegetables. Coatings, $8(5)$. https://doi.org/10.3390/coatings8050152

(13) R. N. Tharanathan, Biodegradable films and composite coatings: past, present and future. TIFST, 14. pp. 71-78 (2003)

(14) F. G. Winarno. Kimia Pangan dan Gizi. (Gramedia Pustaka Utama, Jakarta 2004)

(15) F. H. G. Peroni, T. S. Rocha, C.M.L. Franco, Some structural and physicochemical characteristics of tuber and root starches. Food Science and Technology International, Vol.12(6): 505-513 (2006)

(16) Nogueira, G. F., Fakhouri, F. M., \& de Oliveira, R. A. (2018). Extraction and characterization of arrowroot (Maranta arundinaceae L.) starch and its application in edible films. Carbohydrate Polymers, 186(January), 64-72. https://doi.org/10.1016/j.carbpol.2018.01.024

(17) S., Guilbert. Technology and application of edible protective films. Pages 371-394 in: Food Packaging and Preservation-Theory and Practice. M. Mathlouthi, (ed. Elsevier Applied Science: New York 1986)

(18) D. R. Lineback, , \& G. E. Inglett,. Food carbohydrates. (Westport, CT: Avi Publishing Co. 1982)

(19) Suppakul, P., Chalernsook, B., Ratisuthawat, B., Prapasitthi, S., \& Munchukangwan, N. (2013). Empirical modeling of moisture sorption 
characteristics and mechanical and barrier properties of cassava flour film and their relation to plasticizing-antiplasticizing effects. $L W T$ Food Science and Technology, 50(1), 290-297. https://doi.org/10.1016/j.lwt.2012.05.013

(20) A. Cagri, Z. Ustunol, and E.T. Ryser. Antimicrobial edible films and coatings. Journal of Food Protection 67: 833-848 (2004)

(21) Garcia, L. C., Pereira, L. M., De Luca Sarantópoulos, C. I. G., \& Hubinger, M. D. (2012). Effect of antimicrobial starch edible coating on shelf-life of fresh strawberries. Packaging Technology and Science, 25(7), 413425. https://doi.org/10.1002/pts. 987

(22) N., Gontard, S. Guilbert, and J.L. Cuq. Edible wheat gluten film: Influence of the main variable on film properties using response surface methodology. Journal of Food Science 57: 190199 (1992.)

(23) Santacruz, S., Rivadeneira, C., \& Castro, M. (2015). Edible films based on starch and chitosan. Effect of starch source andconcentration, plasticizer, surfactant's hydrophobic tail andmechanical treatment. Food Hydrocolloids, 49, 89-94. https://doi.org/10.1016/j.foodhyd.2015.03.019

(24) Fakhouri, F. M., Martelli, S. M., Caon, T., Velasco, J. I., \& Mei, L. H. I. (2015). Edible films and coatings based on starch/gelatin: Film properties and effect of coatings on quality of refrigerated Red Crimson grapes. Postharvest Biology and Technology, 109, 57-64. https://doi.org/10.1016/j.postharvbio.2015.05.015

(25) Bonilla, J., Vicentini, M., Dos, R. M. C., Bittante, Q. B., \& Sobral, P. J. A. (2015). Mechanical properties of cassava starch films as affected by different plasticizers and different relative humidity conditions. International Journal of Food Studies, 4(1), 116-125. https://doi.org/10.7455/ijfs/4.1.2015.a10

(26) Skurtys, O., Acevedo, C., Pedreschi, F., Enronoe, J., Osorio, F., \& Aguilera, J. M. (2011). Food hydrocolloid edible films and coatings. Food Hydrocolloid Edible Films and Coatings, 1-66.

(27) Cisneros and Krochta. (2003). Dependence of Coating Thickness on Viscosity of Coating Solution Applied to. Journal of Food Science, 68(2), 503-510.

(28) L.R. Howard, and T. Dewi. Sensory, microbiological and chemical quality of minipeeled carrots as affected by edible coating treatment. J. Food Sci. 60: 142-144 (1995)

(29) Warkoyo, Raharjo, B., Marseno, DW., Karyadi, J. (2014). Sifat Fisik, Mekanik Dan Barrier Edible Film Berbasis Pati Umbi Kimpul (Xanthosoma
Sagittifolium) Yang Diinkorporasi Dengan Kalium Sorbat. Agritech, 34(01), 72-81. https://doi.org/10.22146/agritech.9525

(30) X.Y., Xu, K. M., Kim, M. A. Hanna and D. Nag. Chitosan-starch composite film: preparation and characterization. Industrial Crops and Products 21:185-192 (2005)

(31) Su, J. F., Huang, Z., Yuan, X. Y., Wang, X. Y., \& Li, M. (2010). Structure and properties of carboxymethyl cellulose/soy protein isolate blend edible films crosslinked by Maillard reactions. Carbohydrate Polymers, 79(1), 145-153. https://doi.org/10.1016/j.carbpol.2009.07.035

(32) Chiumarelli, M., \& Hubinger, M. D. (2012). Stability, solubility, mechanical and barrier properties of cassava starch - Carnauba wax edible coatings to preserve fresh-cut apples. Food Hydrocolloids, 28(1), 59-67. https://doi.org/10.1016/j.foodhyd.2011.12.006

(33) E. Purnomo. Pengetahuan Dasar Teknologi Penyamakan Kulit. Akademi Teknologi Kulit. Yogyakarta (1985).

(34) Prasetyo, A., Prasta, D. M., Arum, A. D., Islami, B. Y., Lee, A., \& Winarti, S. (2018). Karakteristik Edible Coating Dari Pati Umbi Udara (Air Potato) Dengan Penambahan Plasticizer Yang Berbeda. Jurnal Teknologi Pangan, 12(1), 18-26. https://doi.org/10.33005/jtp.v12i1.1097

(35) Rusli, A., Metusalach, Salengke, \& Tahir, M. M. (2017). Karakterisasi Edible Film Karagenan Dengan Pemlastis Gliserol. Jphpi 2017, 20(November), 219-229.

(36) Hidayati, S., Zuidar, A. S., \& Ardiani, A. (2015). Aplikasi Sorbitol Pada Produksi Biodegradable Film Dari Nata De Cassava. Reaktor, 15(3), 195. https://doi.org/10.14710/reaktor.15.3.195-203

(37) Šuput, Danijela (Faculty of Technology, N. S. (Serbia)), Lazić, Vera (Faculty of Technology, N. S. (Serbia)), Jelić, Aleksandra (Faculty of Technology, N. S. (Serbia)), Lević, Ljubinko (Faculty of Technology, N. S. (Serbia)), Pezo, Lato (Institute of General and Physical Chemistry, B. (Serbia)), Hromiš, Nevena (Faculty of Technology, N. S. (Serbia)), \& Popović, Senka (Faculty of Technology, N. S. (Serbia)). (2013). The effect of sorbitol content on the chracteristics of starch based edible films. Journal on Processing and Energy in Agriculture, 17(3), 106-109. Retrieved from http://scindeksclanci.ceon.rs/data/pdf/1821-4487/2013/182144871303106S.pdf 
